\title{
Education for Developing a Global Omani Citizen: Current Practices and Challenges
}

\author{
Saif Al-Maamari ${ }^{1}$ \\ ${ }^{1}$ Faculty of Education, Sultan Qaboos University, Muscat, Oman \\ Correspondence: Saif Al-Maamari, Faculty of Education, Curriculum and Instruction Department, Sultan Qaboos \\ University, Muscat, Oman, B.O 32, PC 123.
}

Received: April 30, 2014

Accepted: May 23, 2014

Online Published: June 10, 2014

doi:10.11114/jets.v2i3.399

URL: http://dx.doi.org/10.11114/jets.v2i3.399

\begin{abstract}
Oman is a developing country which reformed its educational system in 1998 in order to meet the challenges of the $21^{\text {st }}$ century, especially economic challenges. Strength of national identity and developing a sense of global citizenship were among the priorities of the new educational reform. This paper is based on a review of current practices regarding global citizenship education in educational system. The purpose of this theoretical study was to explore the current provision of the aspects of global citizenship education in Omani schools. Specifically, the study attempts to identify the current practices that are implemented by Omani schools to help Omani students to develop a sense of effective global citizenship. The study indicates that Omani education is not nationally centered as it aims to develop students who have global awareness. The study shows employing different approaches to develop a sense of global citizenship, namely, a separate school subject; integrated theme in social studies education, participation in some international initiatives in global citizenship education, and celebrating the international days and decades.
\end{abstract}

Keywords: global citizenship, global Omani citizen, Current practices of global citizenship, education in Oman.

\section{Introduction}

Citizenship has attracted intensive discussions in the last two decades. Currently, citizenship is "riding high on the political and social policy agendas of many governments" (Sim \& Print, 2009, 380). Historically, citizenship has been linked to independent nation-states as a source of a set of rights and duties. Yet, this relationship between nation-state and citizenship is breaking down by the some forces such as terrorism, climate change, economic turmoil, Global corporations and migration. Ali (2009) argues that globalization expands the international and transnational exchanges around the world by providing fast means of communication and transportation. Robinson, Naumescu and Ives (2009) stressed that the world encounters many environmental problems that if not addressed soon by all countries may reduce the ability of the earth to sustain life as we know it.

Therefore, it is no longer acceptable in the era of increasing integration of the world, and overlapped by the causes of its problems and its implications, to be breeding a local orientation, and national purpose and aspiration. This is because the students should be familiar with the world around them, equipped with the skills to communicate with him and its peoples, as well as have positive values and attitudes of the interaction of rational the official with the various components of human and natural, free from matter and the requirements of discrimination, and negative, in dealing with its affairs and the course of events. In other words, students should have a sense of what has become known in educational literature as "global citizenship" (Al-Maamari, 2010).

These increasing global transformations are mirrored on education. Holford (2001) raises a question about the role of schools in developing a sense of global citizenship. Baildon and Sim (2009) highlighted that education is an important means used by the state to address the challenges of globalization. Duty (2010) emphasized that young citizens should exercise some responsibility for the events that happen around them in the world. Sheppard (2004) regarded global citizenship as "A daily responsibility" (p.35). Therefore, schools are regarded as one critical provider of global citizenship education (hereafter, GCE) as they can stimulate informed daily responsibilities by providing students with learning on global issues. Hence, educational literature showed increasing attention to conceptualize the GCE in the last two decades (Tye \& Tye, 1992; Merryfield, 1998; Wilson, 2001; Osler \& Vincent, 2002; Ukpokodu, 2006).

The idea of GCE has evolved since the middle of last century. Lee and leung (2006) mentioned three different terms 
which have been used in the educational literature to refer to GCE. These are world studies which have taken place in the early twentieth century; international education promoted after World War II, and then global education and education for interdependence.

Several scholars in the filed of global education and GCE stress on making a shift from education students solely for national-based citizenship to educate them for effective global based citizenship in the $21^{\text {st }}$ century. However, the question is whether this shift is possible during a time when many countries focus on consolidating their identity in the globalized world. Oman is a country that is attempting to prepare its students to be global citizens. This article is timely as an original as it is the first article that aims at documenting and representing the provision of GCE in one Arabic country, namely Oman. It is hoped that this article will fill a gap in the international literature about citizenship education in general and GCE in particular in Arab countries. This article consists of four main parts: (a) literature review; (b) the context of the study; (c) the current practices of GCE in Oman; and (d) the discussion and conclusion.

\section{Literature Review}

\subsection{Citizenship Education}

The contested nature of citizenship, as has been mentioned earlier, leads to different meanings of CE. In the literature, different concepts were used to refer to CE: citizenship education, education for citizenship, education about citizenship, education in citizenship, education for democratic citizenship, civic education, civics, and global CE. Actually, these different concepts were used to differentiate between a maximal and a minimal CE (Al-Maamari, 2009a).

The minimal concept of CE stresses knowledge about citizenship instead of developing a sense of participation among the students. In fact, this understanding of $\mathrm{CE}$ makes students passive in the classroom as the teachers use only traditional methods of teaching. Marsden (2001), Griffith (1998), Kerr (1999) and Nelson and Kerr (2005) regard this kind of education as education about citizenship. Kerr (1999) and Nelson and Kerr (2005) argue that the minimal concept of CE is sometimes referred to as civic education, which is content-led, teacher-based, whole-class teaching and examination-based assessment. However, the maximal concept of CE is comprised of knowledge, values and skills, and aims to prepare students for active, responsible participation in school and beyond. Unlike narrow CE, it extends learning beyond the curriculum and classroom to all activities inside and outside school. In addition, it is highly dependent on interactive teaching, which requires discussion, debate and the creation of many opportunities for students to participate effectively (Kerr, 1999; Nelson \& Kerr, 2005).The latter concept of CE is adopted in the most recent innovations of developing CE in Western countries. According to Collado and Atxurra (2006, p.206), CE

'Can be understood as the knowledge, means, and activities designed to encourage students to participate actively in democratic life, accepting and exercising their rights and responsibilities.'

\subsection{Global Citizenship Education}

It is clear from the current literature that education for global citizenship is an umbrella which cover overlapping themes, namely education for tolerance and appreciation of diversity, conflict resolution and peace, human rights education and education for sustainable development (Tawil, 2013). According to Oxfam (2006), education for global citizenship aims to develop a global citizen who is aware of the wider world and has a sense of their own role as a world citizen; respects and values diversity; is willing to act to make the world a more equitable and sustainable place; and takes responsibility for their actions. For Davy (2011), building a global awareness is require to focus on several elements which include cultural and perspective awareness, additional language learning-multilingualism, international-mindedness, critical thinking skills, and research and IT skills. Tawil (2013) highlights the importance of making the knowledge, skills, values more relevant to the participation of citizens in the world development at local and global levels. If we need citizenship to be more meaningful from view point of Munck (2010), it is crucial to foster GCE which stresses on building a sense of responsibility to the world.

From above, It is evident that education for citizenship and education for global citizenship are both a broad processes that take place in school and beyond. It is not confined to transmitting knowledge to the student but is also concerned with equipping them with skills and values in order to make them effective and responsible citizens in their country and beyond.

\section{Context of the Study}

\subsection{Geographical Context}

The history of Oman can be dated back at least 5,000 years, establishing Oman as an ancient civilization. Historical documents refer to several names of Oman, namely; Magan (copper mines), Mazoun (plentiful water) and then Oman (MOI, 2002). Geographically, Oman occupies the extreme southeastern part of the Arabian Peninsula. It has a total land area of 309,500 square kilometres and it is the third largest country in the Arabian 
Peninsula. The country is bordered by Saudi Arabia and the United Arab Emirates to the west, the Yemen Republic to the south, the Arabian Sea to the east, and the Strait of Hormuz to the north (MOI, 2004).

\subsection{Biographical Context}

Biographically, Oman population is 2.33 million people according to the latest census carried out by the Ministry of National Economy (MONE) in 2003. The Omani people are composed of 1.77 million nationals; the remainder are of around 0.552 million being immigrants. The majority of people are Arab and the others belong to one of three main ethnic groups: the Hyderabadi, the Balushies and the Zanzibari (Arabs of Omani descent who lived in Zanzibar for many years and returned to the country after 1970). These communities are different in terms of cultural heritage, language, dress and religious or sectarian affiliation (Al-Humamai, 1999) Islam is the religion of the country. The majority of the population is Ibadhi while the remaining population is divided between the Sunni and the Shi'a sects. Arabic is considered the official language in Oman; however, several languages are spoken by inhabitants such as English, Urdu, Baluchi and Swahili (Al-Maamari, a2009).

\subsection{Economical Context}

With regard to the economy, Oman is an oil producing country and most of its income is generated from this industry. However, the production capacity of Oman is small in comparison to other Gulf Countries. In 2001, Oman produced only 956,000 barrels daily, a yearly total of 349 million barrels of crude oil and petroleum condensates (MOI, 2002). However, Oman has attempted to reduce over-reliance on Oil by diversifying the economic sources and developing Omani human capital by building a modern education system.

\subsection{Political Context}

GCE in Oman is promoted by enlightenment of the leadership of his Majesty of Sultan Qaboos who took over power in 1970. Then, the Oman government has established friendly ties with all countries around the world. This policy was confirmed by his Majesty in his speech to the annual session of the Council of Oman on the fourth of November 2002, saying: "Our foreign policy known to all, we are always to the side of right, justice, friendship and peace. In addition, we call for peaceful coexistence among nations and to understanding between civilizations and to eradicate the causes of hatred and resentment generated in the hearts of those who suffer injustice and inequality" (http://www.omanet.om).

Oman supports a range of international initiatives in the environmental and cultural fields in order to support peace and mutual understanding in the world. Environmentally, the Sultan Qaboos Award to safeguard the environment can be regarded as the first Arabic prize is awarded at the global level. This award was established in 1989 and was welcomed by UNESCO. The prize is awarded every two years through a program (MAB) of UNESCO in recognition of outstanding contributions of individuals, groups, institutions and organizations in the field of environmental protection. Silk road is a cultural project that was adopted by Oman in cooperation with UNESCO in order to study the silk road and the leading role that Oman played in the process of human communication between East and West. This journey started on October 1990 and ran until March 1991. In all, 182 studies were presented in 19 international seminars during the period of this journey.

Furthermore, Oman sponsors and supervises a number of international academic chairs in cooperation with some international universities in the following fields:

- Sultan Qaboos chair of Arabic Language study which was launched in the People's Republic of China on July 4, 2007.

- The Chair of Sultan Oman of Oriental Studies, University of Leiden, the Kingdom of the Netherlands which was launched on November 4, 2008.

- Sultan Qaboos Chair in the field of water management, economic diversification at the Academy of Roosevelt at the University of Utrecht in the Hague, the Netherlands in 2005.

- Chair of his Majesty Sultan Qaboos for contemporary Arab Studies at the University of Cambridge British, Faculty of Oriental Studies, which was established in 2005.

- Sultan of Oman international Fellowship in Arts and Humanities and Social Sciences Oxford Centre for Islamic Studies which was established in 2005 at the University of Oxford in Britain.

- Chair of his Majesty Sultan Qaboos of Arabic and Islamic Studies at the University of Melbourne, was established in 2003.

- Chair of his Majesty Sultan Qaboos of Information Technology at the University of Engineering and Technology of Pakistan, was established in 2001. 
- Chair of his majesty Sultan Qaboos in International Relations Harvard University of America, was Established in 1999.

- Chair of sultan Qaboos in the field of culture desert at the University of Arabian Gulf was established in 1994. Chair of his Majesty Sultan Qaboos of Arabic and Islamic Studies at the University of Georgetown, was established in 1993.

From the above, it appears that Oman has a belief of providing the world with the contributions that can enhance its prosperity. Oman, has not been involved in any conflict either with its closer neighbours or with the rest of the world. Therefore, Oman gives priority to educate its generations to develop a set of values such as peace, cooperation, cultural dialogue, coexistence, and tolerance. These values were mirrored in last educational reform in the curriculum.

\subsection{Educational Context}

Modern education in Oman began in 1970 when Sultan Qaboos came to rule. Before 1970, informal education was available in some areas across the country but it was available only for boys and was very poorly equipped. However, the new government expressed its commitment to build the country's infrastructure. The ruler of the state considered education as a normative priority that entailed a quick response from the government. Therefore, the motto 'we shall educate our children even in the shadow of trees' was created by Sultan Qaboos, who was fully conscious of the role that education plays in building a strong, dynamic state (Ministry of Education, 1996).

In the past 43 years, education in Oman has undergone remarkable developments, both quantitatively and qualitatively. From the previous development of education in Oman, it is possible to argue that education in Oman has actually undergone two periods: a quantitative period, which began in 1970 and continued until 1995, and was marked by the distribution of learning for all Omani areas; and a qualitative period, which started in 1998 with the implementation of BE.

According to article 13 of the State's Constitution, Omani education aims to achieve the following broad goals (MONE, 1999, pp.43-44):

- 'Education is a fundamental element for the progress of society which the state fosters and endeavours to make available to all.'

- 'Education aims to raise and develop general cultural standards, promote scientific thought, kindle the spirit of enquiry, meet the needs of the economic and social plans, and create a generation strong in body and moral fibre, proud of its nation, country and heritage, and committed to safeguarding their achievements.'

The State's Constitution also subscribes to the following with regard to the role of state in education matters (MONE, 1999, pp.43-44):

- 'The state provides public education, combats illiteracy and encourages the establishment of private schools and institutes under state supervision and in accordance with the provision of the Law.'

- 'The State fosters and conserves the national heritage, and encourages and promotes the scientific literature and scientific research.'

The MOE (2001b) defined Basic Education (BE) as a unified ten-year education provided by the Sultanate for all children of school age. It aims to provide the pupils with knowledge, skills, attitudes and values, enabling them to continue their education or training based on their interests, aptitudes, and dispositions. Since 1998, the MOE has gradually replaced the former education system with the BE (from grades 1 until 10). The replacement was completed in the school year 2006/2007. The educational programme is divided into two stages: BE (ages 6-15) and post-BE (ages 16-17). BE further splits into two cycles: the first cycle (ages 6-9) and the second cycle (ages 10-15) (Al-Kindi, 2005, 3-6).

In Post-BE, students are required to choose school subjects in each grade (11 and 12). These subjects are to provide the students with the required basic skills in order to prepare them to practise a profession in the future. In addition, students also have to study a 'research method' subject and then conduct a theoretical or applied project. There are two groups of subjects that students have to study: one is compulsory while another is optional, from which students should choose only three subjects (MOE. a2007). The number of students in the school year $2010 / 2011$ amounted to 530,652, of whom 270,357 were males and 260,983 females. These students were distributed to the 1039 governmental schools and were taught by 40986 Omani teachers (14473 males \& 26473 females) (Al-Maamari, 2010).

In 1978, the Ministry of Education formulated a clear philosophy to guide educational system and development of curriculum. According to this document, education in Oman aims to achieve the following broad goals: 
- The whole growth of the individual.

- Originality and identity of Oman

- National Unity

- National pride and strength

- Social emancipation

- Promotion of international peace and understanding

- The contemporary world and its challenges

- The overall development of the Omani society

- Consolidation of the principles of the Islamic faith and pride in the development of Islam.

Oman, as was prescribed in its educational philosophy, hopes to educate its citizens to be rational, open, balanced, and flexible in their interaction with their heritage, customs, and values on the one hand and in the way of dealing with modern civilization and achievements of technology on the other hand. The principles contained in this document emphasizing the provision of progressive education are centered on the individual, the community, and the world.

\section{The Current Practices of GCE in Oman}

\subsection{Global Education at Basic Education Level}

The main concern of Basic Educational is providing pupils with a balanced education in the social, emotional, intellectual, and physical spheres. The curriculum of this stage focuses on basic learning skills: reading, writing and mathematics in addition to promote national identity among pupils. National identity is developing by studying Arabic language, Islamic education and social studies. However, the curriculum attempts to help student to develop a more outward looking by making English language a compulsory subject to all pupils from the first school year on since school year 1998/1999.

\subsection{Global Education at Post-basic Education Level}

The purpose of post-basic education is to help students to acquire knowledge, to develop competencies, and to encourage critical thinking. Global education in this stage is introduced in different ways. One of them is developing international understanding and intercultural learning through teaching English. In addition, GE is also developed through teaching social studies, Islamic cultural, life skills, and geography. For instance, the "World around me" is as an optional social studies course which was introduced in school year 2006/2007 for grade 12 . The main purpose of this course is to broaden student's perspectives about the present and future challenges of the world. This aim was reflected in units of the course which come under the following headings: Our world is rapidly changing world, Energy between reality and the future, Our diverse cultures, The inevitability of dialogue: Me and others, World heritage, and How can be happy in our world. It was stated in the textbook that "the way to reach a better understanding between peoples and nations in our world is to build a long relationship between cultures and civilizations based on intimate knowledge of the reality we live in this era" (Ministry of Education, 2007, p.165). According to the recent national educational literature, some global issues are integrated in social studies courses. Al-Mahrouqi (2004) conducted a study aimed to identify the extent of inclusion of children is rights in social studies textbooks for grades (3-6). The study revealed that the textbooks covered to varying degrees the children rights with most attention was given to economic, social, civil and cultural rights. In contrast, the family rights and political rights did not receive the appropriate amount of attention. Al-Amery (2006) conducted a study sought to reveal the extent of inclusion this value in social studies textbooks in grades (5-10) in Oman. The findings suggest that social studies textbooks include the concepts of cultural of tolerance, but in a disorganized and random. In addition, the focus was to develop cultural tolerance in society, school whereas the culture of tolerance in the family did not receive due attention. Al-Rahbi (2009) conducted a study aimed at discovering the inclusion of the concepts of human rights in social studies textbooks in grades (3-12). The findings of the study showed that educational and cultural rights received the greatest attention in all textbooks. Al-Maamri (b2009) conducted a study in order to identify how social studies textbooks for grades (5-10) of Basic Education depict women. The textbooks were analyised according to a list of vocabulary images were prepared by the researcher. The study showed that textbooks give attention to women in different fields such as social, health, education, politics and economics. However, the image of women in security, safety, cultural, and media fields did not receive appropriate attention. Al-Rabani (2009) examined the inclusion of some global issues in the social studies textbooks (grades 3-12). The population of the study included all (14) social studies textbooks. The results showed that social studies text books included five out of six global issues included in the analysis check 
list: economic issues, issues of developing countries, environmental issues and population issues whereas political issues were not included.

This national trend of focusing on integrating GCE in social studies is consistent with global trends. In other worlds, it is will documented that developing citizenship is the main purpose of social studies (Sears, 1996; Osborne, 1997; Print, 2000; Sim, 2010; Sim, 2011). Yet, this is not the only approach to develop a GCE as will be shown in the next section.

\subsection{GCE in Extra-school Activities and Projects}

Based on integrating the global issues in social studies, some Omani schools are involving in international projects and global events that aim to build awareness of global responsibility, and to build bridges of communication between students in different countries in the world. Some schools are currently involved in the following global education initiatives (Al-Maamari, 2010).

\subsubsection{Global Project}

Global is an abbreviation of "global Learning and observations to benefit the Environment". The program was implemented under an agreement of understanding signed on December 8, 2009 between the Sultanate of Oman, represented by the Ministry of Education and the United States of America, represented by management National Aeronautics and Space Administration (NASA). The main aim of the program is to improve students' environmental awareness through focusing on the following aspects: understanding the facts and data place Earth science in a scientific manner. In addition, the program attempts to improve the level of academic achievement for students in science, social studies and mathematics. Moreover, it hopes that the program will increase internet employment in scientific research and communicate with the outside world, leading to stronger ties and cultural knowledge among the students participating in the program. The development of the spirit of citizenship and belonging and the preservation of the environment are among the goals of the program. Achieving the goals of the program required preparation of scientific research in different fields of environmental aspects including: the atmosphere, water, soil, and the surface of the earth/biology and phenology which is looking at the relationship between climate and periodic biological phenomena. In addition, the students can prepare an environmental information base and share with countries participating in the program. Also, the goals can be obtained by organizing competitions between the schools participating in the program and through engaging in dialogue over the internet.

\subsubsection{Professional Journalist Project}

Omani schools are the first schools in the Arab world to participate in this program. The program is implemented by the support of the joint Convention of the Initiative Middle Eastern (MEPI) adopted by the U.S Embassy and the Organization (IEAPN) in collaboration with the center for Academic Cooperation (AED) United States of America. This program was implemented by four Omani schools in the Northern Batinah District in the school year 2009/2010. The participating schools launched newsletters in Arabic and English, the web site of the project and e-forums in school.

\subsubsection{UNESCO Associated Schools Project}

The associated schools project is a global project which has been implemented by many schools around the world since it was initiated in 1953. The project is referred to as a 'network of schools affiliated to UNESCO. This program aims to support international understanding, peace, and dialogue between cultures and sustainable development, and quality of education in practice. Generally the schools' network focuses on the following areas: the priorities of the United Nations, Education for sustainable development, education for peace and human rights, and Intercultural learning. (http://www.unesco.org): Omani schools joined this network in 1998 on a trial basis after a through study of the objectives and activities of this network. Two high schools started implantation of this program and third school added in 1999. Two new schools were added in 2000. The number of affiliated schools becomes 14 by the school years 2006/2007.

\subsubsection{Connecting Cultures}

This project was initiated in 2007 by Mark Evans, a teacher in the British school in Muscat. This project is supported by the Ministry of Education, and Oman National commission for Education, Culture and Science, in cooperation with UNESCO, and the Islamic Educational, Scientific and Cultural Organization (ISESCO). The project was selected twice by the alliance of Civilizations Forum which is affiliated to the United Nations as one of the leading civil society initiatives. This initiative aimed at promoting dialogue and changing negative images between the two cultures: Western and Arab. 
Among the trips that were organized by the "connecting cultures' is the trip to the sands of Eastern Oman for a distance of $100 \mathrm{Km}$. The participants were 15 young people aged 17-19 years from six different countries (Oman, Saudi Arabia, the United Kingdom, Pakistan, Fiji, and Jordan). During the trip the participants discussed their perspectives about the world in 2030 in term of peace, justice, cultural and religious respect. This project was profoundly influenced by participants perceptions and visions bout other cultures. For example, Sean Coyle from the UK stated

"At first it was somewhat difficult to talk to each other at length due to the language barrier. However, we discovered later that we can with a little patience exchange serious dialogue. In general, I learned a lot about Islamic religion from the participants from Oman, Saudi Arabia and Jordan" (Quoted in Al-Maamri, 2010)

\subsubsection{Global Citizen Project}

This project was lunched in 2009, and aimed at linking classrooms in a number of schools across the Middle East. The program is working to link the classrooms to build sustainable partnerships between schools in the UK and other schools in the world in order to develop mutual understanding and trust between young people in various communities to create a safe world. The program is implemented by support from of British Council in each country. There are currently more than 66,000 students in 300 schools participating in this program and exchange experiences and knowledge about the local cultures (www.britishcouncil.org / connectingclassrooms).

The students from the age group 11-14 years are invited to provide applications that reflect what global citizenship means to them. The participants are required to represent their participation through posters, songs, poems, presentations, articles in magazines or newspapers. The awards include a trip to the UK for all the wining schools in each country.

\subsubsection{The Celebration of World Days}

Another approach to develop a sense of global citizenship in Omani schools is celebration of world decades, years and days which are devoted to a range of environmental, social, cultural, health aspects. For example, some Omani schools are involved in The Green Wave Campaign for the billion trees which is a global campaign aimed at preserving the environment, based on planting a tree in each country in the world on the international day for Biological Diversity which is celebrated on May 22 of each year. Two Omani schools, Rayhana bint Zeid School and Shinas School participated for first time in this campaign in the school year 2009/2010. Currently, the number of participating schools in this campaign so far 23 schools of various levels of education (www.greenwavecbd.int).

\section{Discussion and Conclusion}

In this study I have explored the provision of GSC in the context of Oman, based on policy and literature analysis. Overall, it is clear from this review that in the Omani context GCE is developed in three approaches: as an optional separate subject (World around me) and in some instances is integrated in social studies, and as extra-curricular activities (Participation of some schools in GCE initiatives). Offering the students different opportunities for learning about the world might result in developing a sense of global citizenship. However, several aspects need to be developed in order to make the current channels more fruitful.

First, teachers are regarded one of the most important factors in developing a sense of global citizenship. A recent study conducted by Al-Maamari (a2009) about citizenship education in social studies initial teacher education showed that both the tutors and the student teachers experienced the limited and traditional implementations of citizenship education in the preparation programme of social studies. This result related in the dissatisfaction of the policy-makers, especially from the Ministry of Education, about the inadequate preparation of teachers to develop citizenship. Therefore, the absence of adequate GCE provision in both initial teacher education and in-service teacher education is an impediment. Unless GCE becomes an integral element in teacher education and training, teachers might not able to develop GCE as has been stated in the policy documents.

Second, the international curriculum initiatives implemented currently by some Omani schools require a paradigm shift away from pedagogies that favour acquisition of discrete assessable learning outcomes towards a more holistic interpretive and inquiry-based approach. - Students require direct-experience in studying in order to develop a sense of global citizenship. Teachers should be models for their students in the vocabulary they use to describe other people, races, religions. They should provide students with opportunities to discover and discuss the global issues. Although the new educational reform in Oman stresses on employing interactive teaching methods, the findings of some national studies showed that teacher-centered methods still to some extent dominate in Omani school This result is supported by the findings of other Omani studies (Al-Rabani, 1995; 
Al-Hammami, 1999; Al-Ryami, 2002; and Al-Sekati, 2002).

Third, global citizenship is still associated with the social studies field as showed by some studies that have been until now conducted in Oman. Therefore, the role of other subjects such as English, geography, science and Islamic culture, needs to be consolidated in order to make GCE more effective.

In general, the present study has brought more issues than answers which need further inquiry in the following lines. Firstly, the Investigation of GCE in Oman education is timely because of the impacts of globalization and profound national changes. Secondly, exploring how GCE is conceptualized is timely. In other words, examining whether the current educational reform in the last decade provides good opportunities for the development of the concepts and values of sustainable education and global citizenship and whether it is presented in coherence and diversity in the curriculum or not. Thirdly, although there are currently some practices in the development of education for sustainable development and global citizenship, but today the need is crucial for define the approaches used by every school in the development of global citizenship. Last but not least, evaluation of the effectiveness of taking part on international projects on GCE, which have been already mentioned, on developing global values on Omani students will be crucial at this stage.

\section{References}

Al-Amri, Y. (2006). The extent of inclusion of the concepts of tolerance in the social studies textbooks for grades (5-12) in the Sultanate of Oman, (Unpublished Dissertation MEd, in Arabic), Faculty of Education, Sultan Qaboos University, Oman.

Al-Hammami, H. (1999). Education for the $21^{\text {st }}$ century general education reform in the Sultanate of Oman: Motives, nature and strategies of implementation (Unpublished thesis, $\mathrm{PhD}$ ), University of Birmingham. UK.

Ali, M. (2009). Preparing citizens for a globalized world: the role of the social studies curriculum, International journal of Education for Democracy, 2 (2), 238- 256 , http://scholarworks.iu.edu/journals/index.php/ried/article/viewFile/160/254

Al-Kindi, Z. (2005). Exploring learning styles of the Omani third secondary English as a foreign language school learners (Unpublished dissertation, MPhil), University of Glasgow, Faculty of Education, Uk.

Al-Maamari, K. (b2009). The image of women in social studies textbooks for grades (5-10) of basic education in the Sultanate of Oman (Unpublished Dissertation MEd, in Arabic), Faculty of Education, Sultan Qaboos University, Oman.

Al-Maamari, S. (2010). Educational transformations in the sultanate of Oman in the first decade of $21^{\text {st }}$ century, Oman: Oman Press.

Al-Maamari, S. (a2009). Citizenship education in Initial Teacher Education in the Sultanate of Oman: An exploratory study of the perceptions of student teachers of social studies and their tutors, (Unpublished .Ph.D thesis), The University of Glasgow, Faculty of Education, UK.

Al-Mahrouqi, M. (2004). Rights of the child in the textbooks of social studies in basic education in the Sultanate of Oman: an analytical study. (Unpublished Dissertation MEd, in Arabic), Faculty of Education, Sultan Qaboos University, Oman.

Al-Rabani, A. (1995). An Evaluation of social studies teacher's preparation programme in SQU Faculty of Education from the graduates' viewpoint, (Unpublished Dissertation MEd, in Arabic) Alyarmook University, Gordan.

Al-Rabani, A. (2009). Global issues in Omani Social Studies Textbooks (Grades 3-12). Journal of Educational and Psychological Studies, 3 (1), 1- 23.

Al-Rahbi, K. (2009). The extent of inclusion of the concepts of human rights in the social studies books for grades (3-12) in the Sultanate of Oman, (Unpublished Dissertation MEd, in Arabic), Faculty of Education, Sultan Qaboos University, Oman.

Al-Ryami, A. (2002). An evaluation study of some historical research skills necessary for the History Department Students at the Colleges of Education in Oman, (Unpublished dissertation MEd, in Arabic), Faculty of Education, Sultan Qaboos University, Oman.

Al-Sekati, S. (2002). Evaluating tasks included in the Omani social studies textbooks of the first Cycle of Basic education, (Unpublished Dissertation MEd, in Arabic), Faculty of Education, Sultan Qaboos University, Oman.

Baildon, M., \& Sim, J. (2009). Notions of criticality: Singaporean teachers' perspectives of critical thinking in 
social studies, Cambridge Journal of Education, 39(4), 407-422. http://dx.doi.org/10.1080/03057640903352481.

Collado, M., \& Atxurra, R. (2006). Democratic citizenship in textbooks in Spanish primary curriculum, Curriculum Studies, 38(2), 205-228.

Davy, I. (2011). Learners without borders: a curriculum for global citizenship, International Baccalaureate Organization,http://www.godolphinandlatymer.com/_files/IB/B309322691ABF031CB793E9DDA47FE3A.p df.

Duty, L. (2010). Changing teachers' conceptualizations of teaching for citizenship in Globalized world (Unpublished Ph.D dissertation), The Graduate school of Education, The Ohio State University.USA.

Golmohamad, M. (2009). Education for world citizenship: beyond national allegiance, Educational Philosophy and Theory, 41 (4), 466- 486.

Griffith, R. (1998). Educational citizenship and independent learning, The United Kingdom: Jessica Kingsley Publishers Ltd.

Kerr, D. (1999). Citizenship education: An international comparison, online: http://www.inca.org.uk/pdf/citizenship_no_intro.pdf\#search='David\%20kerr\%20and\%20citizenship\%20education'

Lee, W., \& Leung, S. (2006). Global citizenship education in Hong Kong and Shanghai secondary schools: ideals, realities, and expectations, Citizenship Teaching and Learning, 2 (2), 68-84.

Marsden, B. (2001). Citizenship education: Permeation or pervasion? Some historical pointers, In D. Lambert., \& Machon, P. (Eds.). Citizenship through secondary geography, London: Routledge Falmer.

Merryfield, M. (1998). Pedagogy for global perspectives in education: studies of teachers' thinking and practice, Theory and Research in Social Education, 26, 342-369.

Ministry of Education, Oman (1996). Development of education: The national report of the Sultanate of Oman 1994-1996, Presented to the $45^{\text {th }}$ Session of the International Conference of Education, Geneva.

Ministry of Education, Oman (2001b). Basic education in the Sultanate of Oman: A guide to the second cycle: grades 5-10 (Unpublished document, in Arabic), Oman.

Ministry of Education, Oman (2009). The philosophy and objectives of education in the Sultanate of Oman (Unpublished document, in Arabic), Ministry of Education.

Ministry of Education, Oman. (a2007). The programme of Post-Basic Education for grades 11 \& 12 (Unpublished document, In Arabic), Oman.

Ministry of Education, Oman. (b2007). The world around me, Oman: Ministry of Education.

Ministry of Information, Oman (2004). Oman 2003/2004. Oman: International Printing Press.

Ministry of Information, Oman. (2002). Oman 2002, Oman: International Printing Press.

Ministry of National Economy, Oman. (1999). Oman: the Development Experience, Oman: Mazoon Printing Press.

Munck, R. (2010). Civic engagement and global citizenship in a university context: core business or desirable add-on? Arts and Humanities in Higher Education: An International Journal of Theory, Research and Practice, 9(1), 31-41. http://dx.doi.org/1177/1474-022209350102.

Nelson, J., \& Kerr, D. (2005). International review of curriculum and assessment frameworks: Active citizenship: definitions, goals and practices, Background paper, National Foundation for Education Research and Qualifications and Curriculum Authority, Online in: http://www.inca.org.uk/pdf/Active_citizenship_background_paper.pdf

Osbornne, K. (1997). Citizenship education and social studies. In I. Wright and A. Sears (Eds.). Trends and Issue in Canadian social studies. Vancouver: Pacific Educational Press.

Osler, A., \& Vincent, k. (2002). Citizenship and the challenge of global education, London: Trentham.

Oxfam, Uk. (2006). Education for global citizenship: a guide for schools, http://www.oxfam.org.uk/ /media/Files/Education/Global\%20Citizenship/education_for_global_citizenship_ a_guide_for_schools.ashx.

Print, M. (2000). Civics and values in the Asia-Pacific Region. Asia-Pacific Journal of Education, 20 (1), 7-20. 
Robinson, M., Naumescu, A., \& Ives, B. (2009). Romanian, Spanish, and US secondary science teacher perceptions of threats to the Biosphere, Acta Didactica Napocensia, 2(3), 45-60.

Sears, A. (1996). Something different to everyone: conceptions of citizenship and citizenship education, Canadian and International Education, 25(2), 1-16.

Sim, J. (2010). Social studies, citizenship and participation, Global Education, 40(2), 58-63.

Sim, J. (2011). Social studies and citizenship for participation in Singapore: How one state seeks to influence its citizens, Oxford Review of Education, 37(6), NA

Sim, J., \& Print, M. (2009). The state, teachers, and citizenship education in Singapore schools, British Journal of Educational Studies, 57(4), 380-399.

Tawil, S. (2013). Education for global citizenship: A framework for discussion, Education Research and Foresight: Working papers http://www.unesco.org/new/fileadmin/MULTIMEDIA/HQ/ED/pdf/PaperN7EducforGlobalCitizenship.pdf

Tye, B., \& Tye, K. (1992). Global education: A study of school change, Albany: State University of New York Press.

Ukpokodu, O. (2006). The Effect of 9/11on preservice Teachers' Perspective s and Dispositions toward Global concerns, Social Studies Research and Practice, 1(2), 179-200.

Wilson, A. (2001). Growing toward teaching from a global perspective: an analysis of secondary social studies pre-service teachers, The International Studies Forum, 1, 127-143.

\section{$(\mathrm{cc})$ EY}

This work is licensed under a Creative Commons Attribution 3.0 License. 